\title{
Updates of Ocular Prostheses A review of biomaterials and design in anophthalmic socket
}

\begin{abstract}
CLAUDIA FLORIDA COSTEA ${ }^{1,3}$, CAMELIA MARGARETA BOGDANICI ${ }^{1 *}$, ALEXANDRU CARAULEANU2*, GABRIELA DIMITRIU³, ANCA SAVA ${ }^{4}$, NICOLETA DUMITRESCU1 ${ }^{1}$, MIHAELA DANA TURLIUC ${ }^{5,6}$, ANDREI CUCU6, MANUELA CIOCOIU7, RALUCA DRAGOMIR ${ }^{8}$, CATALIN MIHAI BUZDUGA ${ }^{9}$

'University of Medicine and Pharmacy Grigore T. Popa, Department of Ophthalmology, 16 Universitatii Str.,700115, Iasi, Romania ${ }^{2}$ University of Medicine and Pharmacy Grigore T. Popa, Department of Obstetrics and Gynecology, 16 Universitatii Str.,700115,lasi, Romania

${ }^{3} 2^{\text {nd }}$ Ophthalmology Clinic, Prof. Dr. Nicolae Oblu Emergency Clinical Hospital, 2 Ateneului Str.,700309, lasi, Romania 4University of Medicine and Pharmacy Grigore T. Popa, Department of Anatomy, 16 Universitatii Str.,700115, Iasi, Romania EUniversity of Medicine and Pharmacy Grigore T. Popa, Department of Neurosurgery, 16 Universitatii Str.,700115,Iasi, Romania ${ }^{6} 2^{\text {nd }}$ Neurosurgical Clinic,Prof. Dr. Nicolae Oblu Emergency Clinical Hospital, 2 Ateneului Str.,700309, Iasi, Romania 7University of Medicine and Pharmacy Grigore T. Popa, Department of Pathophysiology,16 Universitatii Str.,700115,Iasi, Romania ${ }^{8}$ University of Medicine and Pharmacy Grigore T. Popa, Department of Oral and Maxillo-Facial Surgery, 16 Universitatii Str., 700115, lasi, Romania

'University of Medicine and Pharmacy Grigore T. Popa, Department of Endocrinology, 16 Universitatii Str.,700115,lasi, Romania
\end{abstract}

Since Ancient Egypt up to present day, there have constantly been attempts at creating a perfect ocular prosthesis, which would complement the outstanding deficitin the orbitas a result of enucleation, evisceration and which should be biocompatible with the orbital tissue. Over time, there have been used numerous clinical materials, which were the basis of these eye prostheses. By revising literature through the search engines PubMed, MEDLINE and other sources, this article aims atemphasizing, in a chronological sequence, the way in which different types of ocular prostheses were created, but also their advantages and disadvantages. The evolution and design of biomaterials improved the eye rehabilitation process and reduced the complications caused by these prostheses in the anophthalmic socket.

Keywords: artificial eye, prosthesis, Graves disease, anophthalmic socket, non-integrated implants, integrated implants

The eye is not only the most sensitive organ, but it also plays an important role in the esthetic aspect and facial expression. The loss of an eye can be caused by congenital defect or can be acquired secondary to various disorders, like Graves disease where severe exophthalmia can lead to eye loss [ 1,2$]$. The most common causes which lead to the loss of ocular globe are trauma and tumors [3-5]. In this cases, the surgical intervention must be accurate, because w rong therapeutic steps could cause unnecessary mutilation [6], since there are surgical alternatives in such cases, like ocular surface reconstruction with a very useful biological material, namely, amniotic membrane $[7,8]$. Besides the loss of vision, these patients become affected both esthetically and psychologically. In these cases, such defects are amendable to surgical correction and a multidisciplinary approach including the ophthalmologist, neurosurgeon, maxillofacial surgeon and the ocularist can prove beneficial $[9,10]$. Surgical eye removal was classified in three types: (1) evisceration, during which the contents of the ocular globe are removed with intact sclera, (2) enucleation, during which the entire ocular globe is removed after severing the muscles and optic nerve and (3) exenteration, during which the whole content of the orbit, together with the eyelids, is removed [11, 12].

Modern imagistic techniques and studies on animals have changed the way of understanding anatomy and postenucleation orbitphysiology, since today, we have the proof that by introducing a spherical implant within Tenon's capsule, we can prevent secondary enucleation modifications of orbital volume loss and fat atrophy [1316], even when it is placed late after enucleation [17].
Although over time, orbital implants were developed and inserted in the anophthalmic socket in order to restore ocular globe volume [18], unfortunately, the recovery of eye function by implantation is impossible.

\section{Experimental part}

Matherials and methods

This article aims at emphasizing, in a chronological sequence the way in which diffrent types of ocular prostheses were created and their advantages and disadvantages.

We performed a comprehensive general review synthesizing data from recent relevant studies about the evolution and design of biomaterials, that have been used for ocular prostheses. In this direction we have collected data from the following English medical electronic databases: PubMed and MEDLINE.

\section{Results and discussions}

Since AncientEgypt, Egyptians used to remove the eyes during the process of mummification, in order to fill the orbit with precious stones or wax, to simulate the iris [19]. Even so, the earliest known evidence of an ocular prosthesis was found in Iran, in Shahr -I Sokhta, in the skeleton of a woman, dating back to $2900-2800 \mathrm{BC}$ [20]. This had a hemispherical form, with the diameter of 2.5 $\mathrm{cm}$ and was made of a lightmaterial, probably bitum paste. Its surface was covered by a thin layer of gold, engraved with a central circle, representing the iris and gold lines patterned like sun rays [20, 21]. In 1885, Mules P.H. used a 
spherical hollow glass implant in the case of an eviscerated globe [22].

Once with the anatomical descriptions and the understanding of eye anatomy and visual ways, which prevailed during the sixteenth and seventeenth centuries [23], the first enucleation was made, credited to Georg Bartisch (1535-1607) (fig.1) and published in his Augendienst in Dresden, in 1583 [24].

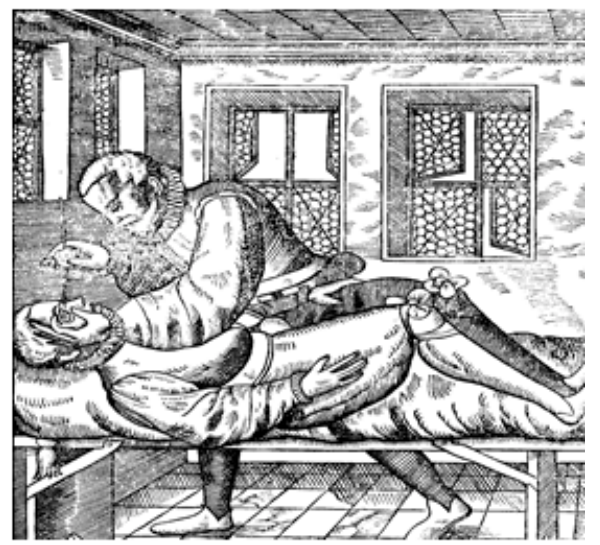

Fig.1. Surgeon at work, modified after an image from Ophthalmodouleia by Georg Bartisch (1583), History of Science Collections, University of Oklahoma Libraries (public domain and U.S. public domain)

Throughout time, the materials used for orbital implants were of the most diverse: metals (aluminium, gold, platinum, silver, stainless steel), minerals and rocks (asbestos, peat), biological materials (bone, cartilage, catgut, fascia lata, coral), organic products (cellulose, agar), polymeric materials (plastic, polymethylmethacrylate -PMMA, polyvinyl, silicone), chemical materials (glass, rubber, tantalum, vitallium), animal products (ivory), hydrocarbons (paraffin, vaseline) or fibers (silk, wool), among which coralline hydroxyapatite (HA), fat, PMMA and silicone [19], are still used today. At present, the most used orbital implants are the bioinert porous ones, made from HA, polyethylene and alumina, which allow the ingrowth of fibrovascular tissue in pores [25].

\section{Types of prostheses}

In ophthalmology, prostheses can be ocular or orbital. Ocular prosthesis represents the artificial replacement of the eye bulb, while orbital prosthesis involves replacing the entire content of the orbit [26]. At the moment, there are three types of ocular prostheses in use: (1) stock eyes, (2) modified stock eyes and (3) custom-fitted eyes [27].

Ocular impressions and fitting can be: direct (external) impression, impression with stock ocular tray, impression with custom ocular tray, impression with stock ocular prosthesis and wax scleral blank [28].

A prosthesis used for ophthalmoplasty must have the following features: (1) retain the shape of the defective socket, (2) prevent collapse of the eye lid shape and accumulation of the fluid in the cavity, (3) provide proper muscle action of the eye lids, (4) maintain aesthetics: palpebral opening, coloration and gaze similar to the natural eye [29]. The prosthetic eye includes: oval whitish outer shell, which must imitate the sclera of the other eye and central round portion painted to look like the iris and pupil of the other eye [21]. In ocular prosthesis, iris button positioning is very important for the aesthetics (fig. 2 and 3).

Modern ocular prostheses have evolved from simply using glass to different types of materials and the simplest classification divides them in two main groups: nonintegrated (non-porous) and integrated (porous) [30].

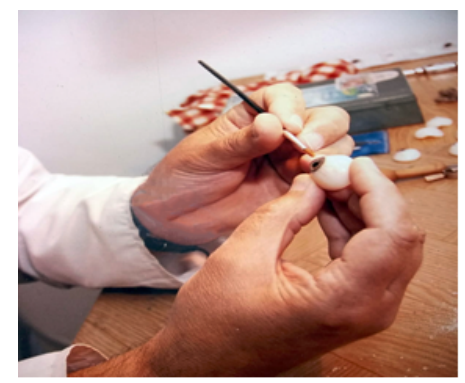

Fig.2. The ocularist paints the iris on the artificial eye (Ocularist's personal collection, Trofin C).

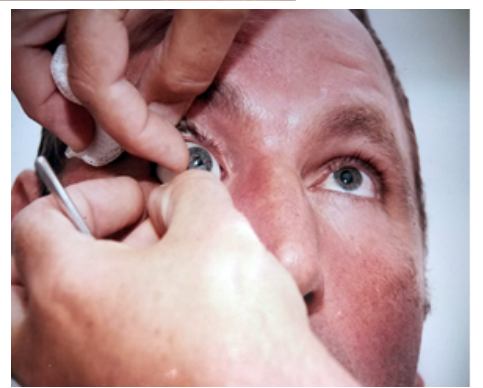

Fig.3. The surgeon makes an incision around the cornea and iris and then removes the intraocular contents, preserving the remaining scleral shell and extraocular muscles.An spherical implant made of acrylic, PMMA, silicone or HA is placed into the evisceration cavity to maintain appropriate orbital volume. The ocularist is fitting the prosthesis after 6-8 weeks following the surgery (Ocularist's personal collection, Trofin C).

Non-integrated implants (non-porous)

Non-integrated implants are characterized by the fact that they do not allow the

ingrowth of organic tissue into their inorganic substance and do not contain a unique apparatus in order to attach extraocular muscles [30]. The main disadvantage of these types of non-porous ocular implants is represented by migration, which occurs more frequently than in porous implants, especially when there are muscles imbricated over the surface of the sphere [31, 32]. Therefore, researchers have sought to cover these implants with different materials which facilitate the fixation of the extraocular muscles, such as polyester gauze or donor sclera, which also improve implant motility [21]. Nonintegrated implants include glass, silicone spheres [33] and PMMA [30].

\section{Glass}

The first glass orbital implant was used by Mules P.H. after evisceration was made in 1885 [22]. It consists of a hollow blown glass sphere and was used largely until the Second World War [34]. The main complication was represented by the extrusion of the glass sphere, which had a rather high rate of $50-90 \%$, as reflected by the study of Mules P.H. [22, 34]. Due to the improvement of surgical techniques, this rate was to decrease over time to $21 \%$ and later, to $10 \%[35,36]$. The main disadvantage of this implant is the risk of break, caused by trauma or the risk of implosion, caused by temperature changes [34]. Moreover, the implant was hazardous, brittle and heavy [37]. Today, glass was abandoned, because better materials for the fabrication of ocular implants were invented. Nevertheless, Baino F. recently published a study in 2018 which proved thatnew glass-ceramic porous material are used for orbital implants, made of foam-like $\mathrm{CaSiO}_{3}$ - containing glassceramics. It presents architectural characteristics, proper to be used as orbital implant material, a promising alternative to existing ceramic or polymeric bioinertorbital implants [38]. 


\section{Silicone}

For more than 50 years, silicone was largely used not only for different types of surgical applications, butalso for orbital implants, due to its beneficial properties: chemical inertia, flexibility, easy handling [34].

At the end of the 1960s, Soll D.B. proposed an inflatable silicone implant, filled with silicone gel [39, 40], which was abandoned because of its pressure-related problems, which occurred both intra-operatory and post-operatory [34]. A few years later, at the end of the 1980s, silicone orbital implants, with non-porous spheres, either bare or wrapped and extraocular muscle cone centered, attached to the four rectus muscles, were introduced [34]. Today, silicone orbital implant is recommended in case of severe orbital trauma, when the extraocular muscles are unidentifiable and cannot be attached to the implant.

\section{Polymethylmethacrylate}

PMMA is an important material in ophthalmology, due to its excellent biocompatibility with ocular tissues and to its transparency [34]. Thanks to these qualities, PMMA is used not only in making intraocular lenses [41] or contact lenses [42], butalso for orbital implants, as well as in fixing extensive orbito-facial defects caused by trauma [43] and useful in neurosurgery and maxillofacial surgery.

PMMA ocular implants appeared in the 1980s, when Frueh and Felker described for the first time, baseball implant, a PMMA sphere in an envelope of sclera [44]. Among the subsequent complications, there were: postoperative edema [45], unacceptable pain, implant exposure or migration [46] or necrosis of the conjunctiva [47].

\section{Integrated implants (porous)}

The porous surface of the integrated implants was proved to allow the fibrovascular ingrowth in depth all over the implant, and also the insertion of posts and pegs [33].

In the absence of a vascular base, this fibrovascular base ingrowth should: (1) lead to the increase of the surgical success rate, (2) decrease the risk of infection, so that this vascular supply allows the defense and immune surveillance and (3) reduce the rate of extrusion or migration of the implant $[19,32,48]$.

This porous surface of the implant helps in anchoring the implant and immune surveillance consecutively [19, 34], in providing blood supply within the implant and in reducing the risk of infection [49].

Moreover, some studies revealed the superiority of the porous implants compared to the one of the non-porous implants. Hence, donor sclera-covered HA implants have higher late exposure rates than sclera-covered silicone implants [48,50]. Also, excellent outcomes by suturing the rectus muscles, reinforced with autogenous fascia or sclera in patients with silicone implant, with no cases of implant migration were obtained [51].

\section{Bone-derived orbital implants}

The first orbital implant of this type was introduced in 1899 , by Schmidt $H$. and it was made from mineral matrix of bovine cancellous bone [52]. The process of creating this implant implied heating spheres of cancellous bone to destroy all organic matter, leaving only calcium phosphate mineral framework behind, which was subsequently proved to contain ultramicroscopic crystals of HA with small quantities of calcium carbonate and calcium citrate [34, 53-55]. These were used until 1950s, when biologically inertnon-integrated polymeric spheres (PMMA and silicone) appeared and took their place [34].

\section{Proplast-Teflon}

Proplast was introduced by Lyall M.G. at the end of the 1970s [56] and it was an inert felt-like composite material, composed of carbon fibers and polytetrafluorethylene (Teflon), out of which hemispherical orbital implants were made, and had the advantage of being invaded by fibrous tissue. Hence, the problem of rejection or extrusion was exceeded [34]. Nevertheless, the use of this type of implant has decreased, mainly due to post-operatory complications, such as long-term infections [57].

\section{Hydroxyapatite}

Due to the chemical similarity to the biological apatite of hard tissues, HA was largely used in the field of oculoplasty.

Introduced by Perry A.C. in 1991 [58], coralline porous $\mathrm{HA}-\mathrm{Ca}_{10}\left(\mathrm{PO}_{4}\right)_{6}(\mathrm{OH})_{2}$ - was to become the most frequently used material in ocular implant after primary enucleation [59]. Made from a specific genus of reef-building coral, porous HA has a similar architecture to human cancellous bone, with interconnecting channels. Per se, HA represents primary inorganic portion of human bones and the process by which implants of $\mathrm{HA}$ are made from sea coral, imply intense heat, which denatures proteins in order to reduce the immune response [19].When it is implanted in soft tissues, porous HA allows the ingrowth of fibrovascular tissues in pores [58], and some studies showed that unw rapped $\mathrm{HA}$ does not become encapsulated, like PMMA spheres or silicone $[58,60,61]$.

Like other ocular porous implants, HA implants allow the fibrovascular ingrowth, reducing the risk of infection, extrusion and migration [62]. Another advantage is the fact that these implants allow the safe attachment of extraocular muscles, improving implant motility $[58,60]$. Studies have also shown that the rate of vascularization depends on the pore dimensions, thus vascular ingrowth was faster in $\mathrm{HA}$ implants with $200 \mathrm{~mm}$ pores than in $\mathrm{HA}$ implants with $500 \mathrm{~mm}$ pores [63]. HA stimulates the occurrence of a foreign-body giant cell reaction [64], and in animal models, this reaction can last up to one year from the orbital implant $[65,66]$.

For a better efficiency, wrapping material for HA implants were looked for, such as temporalis fascia or fascia lata, rectus abdominis sheath, human donor pericardium, expanded polytetrafluoroethylene, bovine pericardium, acellular human cadaveric dermis, polyglactin mesh or polymer-coated HA implants [67-75]. However, the use of $\mathrm{HA}$ implants has decreased in the last time [76].

Nevertheless, porous HA implant presents the disadvantage of having very high costs and causes damage to sea-life ecosystems, as a result of natural corals harvesting [34]. In this respect, an attempt at creating synthetic HA implants was made [77], but the scanning electron microscopy showed that although it has an identical composition to coralline porous HA, there are some architecture-related differences, such as lower porosity and interconnectivity, the existence of closed pores and blind pouches [78]. Despite this, by using a rabbit model study, Jordan et al. proved that the fibrovascularization occurs both in the natural and artificial implant [ 79]

Cheaper versions of this implantwere developed in many countries, with differentresults. Thus, Brazilian HA implant was proved to have a lower porosity and pore interconnectivity and a higher weight than coralline porous HA sphere, with a limited fibrovascularization and increased risk of implant migration [79, 80]. The Chinese HA implant was proved to contain $\mathrm{CaO}$ impurities, and after hydration 
in host tissues, it can result in $\mathrm{Ca}(\mathrm{OH} 2)_{2}$, which is caustic [81, 82].

Other disadvantages and main complications of HA implants are: difficult suture of extraocular muscles directly to the implant, chronic infection, pyogenic granuloma, socket discharge, conjunctival thinning and discomfort or persistent pain [34, 83-87].

\section{Polyethylene (PE)}

$P E$ is a straight-chain, high-density hydrocarbon, made by polymerization of ethylene molecules under pressure and temperature [88].

Porous PE implants appeared at the end of the 1980s, and were considered an efficient and safe alternative to coralline porous HA sphere [89,90], since they could be safely placed, without wrapping [19]. This poly-porous form of PE (Medpor) is made by heating and compacting PE granules in spherical shapes of different size [88]. This material is highly biocompatible, non-toxic and nonallergenic, it is not brittle and allows muscles to be directly sutured, without the need of sclera [91-93] since many studies show favorable surgical outcomes in orbital implantation [94-98].

Studies on PE implants showed that they have even greater advantages than coralline $\mathrm{HA}$, such as less fibrosis and inflammation [99-101], while electron microscopy proved that porous PE implants show a smoother surface than coralline or synthetic HA and aluminium oxide implants $[73,100]$. The main disadvantage is a lower level of vascularization than that of coralline HA [100].

While the first PE implants had a rough surface, like HA [102], PE implants with gradients of porosity were introduced, to which suture tunnels were added, for an easier attachment of the extraocular muscles [103]. In terms of vascularization, studies have revealed that porous PE implants with pore dimensions of $400 \mathrm{~mm}$, vascularize much faster than those of $200 \mathrm{~mm}[99,104]$, and adding synthetic bone graft led to a faster implant vascularization [105].

Throughout time, PE implants were adapted, resulting in a varied number of shapes on today's market: sphere, conical implant, smooth surface tunnel with suture tunnels for easier muscle imbrication, conical orbital implant and Quad motility implant [19,106-108].

\section{Polytetrafluoroethylene}

Expanded porous polytetrafluoroethylene (ePTFE) implants were studied at the end of the 1990s on rabbit models [109]. In spite the fact that fibrovascularization took place in the implants, the authors revealed various degrees of acute and chronic inflammation [109-111].

\section{Aluminium oxide}

Also called alumina, aluminium oxide $\left(\mathrm{Al}_{2} \mathrm{O}_{3}\right)$ was used as orbital implant since 1990s [34]. Studies on animal models showed that alumina is well-tolerated, biocompatible -like HA -and itallows fibrovascular ingrowth $[112,113]$. Even though, initially, cases of aluminum encephalopathy with the use of ionocem - a biomaterial made by reacting polyalkenoic acid with calcium aluminum fluorosilicate - were registered, the blood samples of patients with alumina implants revealed normal levels of aluminum $[113,114]$, and aluminum oxide remained insoluble and bioinert in tissues [19]. In regards to alumina implants wrapped in polyglactin mesh, the results were initially encouraging, with low exposure rates [115]. Subsequent studies were more reserved, proving higher long-term exposure rates [116-118].

\section{Conclusions}

According to the current state of art and orbital implants existing on the market, there is no ideal implant. For all the patients, follow-ups must be done regularly, in order to detect the first signs of potential complications, regardless of the used implant.

\section{References}

1.CHINNERY, H., THOMPSON, S.B.N., NOROOZI, S., DYER, B., Edorium. J. Disabil. Rehabil., 3, 2017, p. 1-10.

2.ZHANG, Y., ZHANG, M. N., WANG, X., \& CHEN, X. F., IJO, 8, no.5, 2015, p.1024.

3.GATON, D.D., EHRLICH, R., MUZMACHER, L., HAMEL, N., LUSKY, M., WEINBERGER, D., Harefuah., 840, 147, 2008, p.758-762.

4.TURLIUC, M.D., SAVA, A., DUMITRESCU, G.F., CUCU, A., Ea ANU, A., TUDORACHE, C., COSTACHE, I.I., COSTEA, C.F., Rom. J. Morphol. Embryol., 56, 2015, p. 1173-1177.

5.GEIRSDOTTIR, A., AGNARSSON, B.A., HELGADOTTIR, G., SIGURDSSON, H., Acta. Ophthalmol., 92, 2014, p.121-125.

6.COSTEA, C.F., TURLIUC, M.D., DIMITRIU, G., BOGDANICI, C.M., MOTOC, A., CHIHAIA, M.A., DANCÃ, C., CUCU, A., CÃRÃULEANU, A., DUMITRESCU, N., INDREI, L., TURLIUC, S., Rom. J. Morphol. Embryol., 58, 2017, p. 739-747.

7.COSTEA, C.F., SCRIPCARIU, I.S., DRAGOMIR, R., DIMITRIU, C., TURLIUC, M.D., DUMITRESCU, G.F., DUMITRESCU, N., VORNICU, V., SAVA, A., CUCU, A., TURLIUC, S., CARAULEANU, A., Rev. Chim. (Bucharest), 69, 2018, p. 1566-1569.

8.SAPTE, E., COSTEA, C.F., CARAUlEANU, A., DANCÃ, C., DUMITRESCU, G.F., DIMITRIU, G., CHIHAIA, M.A., BUZDUGÃ, C.M., CUCU, A., TURLIUC, M.D., Rom. J. Morphol. Embryol., 58, 2017, p. 363-369.

9.ARTOPOULOU, I.I., MONTGOMERY, P.C., WESLEY, P.J., LEMON, J.C., J. Prosthet. Dent., 95, 2006, p. 327-330.

10.PATIL, S.B., MESHRAMKAR, R., NAVEEN, B.H., PATIL, N.P., Gerodontology, 25, 2008, p. 57-62.

11.PERMAN, K.I., BAYLIS, H.I., Otolaryngol. Clin. North. Am., 21, 1988, p.171-82.

12.AGRAWAL, K.K., MALL, P., ALVI, H.A,, RAO, J., SINGH, K., J. Interdiscip. Dentistry, 2, 2012, p. 128-131.

13.KRONISH, J. W., GONNERING, R. S., DORTZBACH, R. K., RANKIN, J. H., REID, D. L., PHERNETTON, T. M., Ophthal. Plast. Reconstr. Surg., 6, 1990, p. 77-87.

14.KRONISH, J. W., GONNERING, R. S., DORTZBACH, R. K., RANKIN, J. H., REID, D. L., PHERNETTON, T. M., PITTS, W. C., BERRY, G. J., Ophthal. Plast. Reconstr. Surg., 6, 1990, p. 88-95.

15.MANSON, P. N., GRIVAS, A., ROSENBAUM, A., VANNIER, M., ZINREICH, J., ILIFF, N., Plast. Reconstr. Surg., 77, 1986, p. 203-214.

16.SMIT, T. J., KOORNNEEF, L., ZONNEVELD, F. W., GROET, E., OTTO, A. J., Ophthalmology, 97, 1990, p. 1347-1351.

17.SMIT, T. J., KOORNNEEF, L., ZONNEVELD, F. W., GROET, E., OTTO, A. J., Ophthalmology, 98, 1991, p. 106-110.

18.SAMI, D., YOUNG, S., PETERSEN, R., Surv. Ophthalmol., 52, 2007, p. 244-265.

19.SAMI, D.A., YOUNG, S.R., Orbital enucleation implants: biomaterials and design in Biomaterials and regenerative medicine in ophthalmology, in: T. CHIRILA (Ed.), Woodhead publishing series in biomaterials, 2010.

20.MOGHADASI, A.N., Iran. J. Public. Health., 43, 2014, p. 1595-1596.

21.YESHWANTE, B., COUDHARY, N., BAIG, N., I.O.S.R. J ournal of Dental and Medical Sciences, 12, 2015, p. 63-67.

22.MULES, P.H., Trans. Ophthalmol. Soc. UK., 5, 1885, p. 200-206.

23.COSTEA, C.F., TURLIUC, S., BUZDUGÃ, C., CUCU, A.I., DUMITRESCU, G.F., SAVA, A., TURLIUC, M.D. Childs. Nerv. Syst., 33, 2017, p. 1889-1898.

24.LUCE, C.M., Int. Ophthalmol. Clinics, 10, 1970, p. 681-687.

25.BAINO, F., POTESTIO, I., Mater. Sci. Eng. C, 69, 2016, p. 1410-1428. 
26KUMAR, CH. S, SAJJAN, C.S., Contemp. Clin. Dent., 1, 2010, p. 201220.

27JAYASWAL, G.P., DANGE, S.P., KHALIKAR, A.N., Indian. J. Dent. Res., 22, 2011, p. 482-485.

28MATHEWS, M.F., SMITH, R.M., SUTTON, A.J., HUDSON, R., J. Prosthodont., 9, 2000, p. 210-216.

29.HAUG, S.P., ANDRES, C.J ., Fabrication of custom ocular prosthesis, in: T.D. Taylor (Ed.), Clinical maxillofacial prosthetics, Quintessence Publishing, Chicago, 2000.

30.SHOME, D., HONAVAR, S.G., RAIZADA, K., RAIZADA, D., Ophthalmology, 117, 2010, p. 1638-1644.

31.ALLEN, L., Ophthalmology, 90, 1983, p. 1116-1120.

32.TRICHOPOULOS, N., AUGSBURGER, J. J., Ophthal. Plast. Reconstr. Surg., 21, 2005, p. 331-336.

33.CHUAH, C.T., CHEE, S.P., FONG, K.S., POR, Y.M., CHOO, C.T., LUU, C., SEAH, L.L., Ann. Acad. Med. Singapore., 33, 2004, p. 477-483.

34.BAINO, F., PERERO, S., FERRARIS, S., MIOLA, M., BALAGNA, C., VERNE, E., VITALE-BROVARONE, C., COGGIOLA, A., DOLCINO, D., FERRARIS, M., Acta. Biomater., 10, 2014, p. 1064-1087.

35.GUYTON, J.S., Trans. Am. Ophthalmol. Soc., 46, 1948, p. 472-527. 36.CULLER, A.M., Trans. Am. Acad. Ophthalmol. Otolaryngol., 56, 1952, p. 17-20.

37.KAIRA, L.S., BHAYANA, R., ASOPA, V., PANDEY, A.N., DABRAL, E., Eur. J. Prosthodont., 2, 2014, p. 33-36.

38.BAINO, F., Mater. Lett., 212, 2018, p. 12-15.

39.SOLL, D.B., Expandable orbital implants, in: A. Turtz (Ed.), Proceedings of the Centennial Symposium, Manhattan Eye, Ear and Throat Hospital, Mosby, St. Louis, 1969.

40.SOLL, D.B., Arch. Ophthalmol., 89, 1973, p. 214-216.

41.BOZUKOVA, D., PAGNOULLE, C., JEROME, R., JEROME, C., Mater. Sci. Eng. R., 69, 2010, p. 63-83.

42.LLOYD, A.W., FARAGHER, R.G.A., DENYER, S.P., Biomaterials, 22, 2001, p. 769-785.

43.GROTH, M.J., BHATNAGAR, A., CLEARHIUE, W.J ., GOLDBERG, R.A., DOUGLAS, R.S., Arch. Facial. Plast. Surg., 8, 2006, p. 381-389.

44.FRUEH, B.R., FELKER, G.V., Arch. Ophthalmol., 94, 1976, p. 429430.

45.TYERS, A.G., COLLIN, J.R., Br. J. Ophthalmol., 69, 1985, p. 438-442. 46.LEATHERBARROW, B., KWARTZ, J., SUNDERLAND, S., BRAMMER, R., NICHOL, E., Eye, 8, 1994, p. 569-576.

47.KAMAL-SIDDIQI, Z., LAL, G., HYE, A., Pak. J. Ophthalmol., 24, 2008, p. 34-36.

48.CUSTER, P.L., KENNEDY, R.H., WOOG, J.J ., KALTREIDER, S.A., MEYER, D.R., Ophthalmology, 110, 2003, p. 2054-2061.

49.CHALASANI, R., POOLE-WARREN, L., CONWAY, R.M, BEN-NISSAN, B., Surv. Ophthalmol., 52, 2007, p. 145-155.

50.NUNERY, W.R., HEINZ, G.W., BONNIN, J.M., MARTIN, R.T., CEPELA, M.A., Ophthal. Plast. Reconstr. Surg., 9, 1993, p. 96-104.

51.NUNERY, W.R., CEPELA, M.A., HEINZ, G.W., ZALE, D., MARTIN, R.T., Ophthal. Plast. Reconstr. Surg., 9, 1993, p. 90-95.

52.SCHMIDT, H., Z. Augenheilkd., 16, 1906, p. 63-80.

53.SCHMIDT, H., Z. Augenheilkd., 23, 1910, p. 321-339.

54.KLEMENT, R., TROMEL, G., Hoppe-Seyler's. Z. Physiol. Chem., 230, 1932, p. 263-269.

55.BREDIG, M.A., Hoppe-Seyler's. Z. Physiol. Chem., 260, 1933, p. 239-243.

56.LYALL, M.G., Trans. Ophthalmol. Soc. UK., 96, 1976, p.79-81.

57.WHEAR, N.M., COUSLEY, R.R., LIEW, C., HENDERSON, D., Br. J. Oral. Maxillofac. Surg., 31, 1993, p. 292-295.

58.PERRY, A.C., Ophthal. Clin. North. Am., 4, 1991, p. 173-182.

59.HORNBLASS, A., BIESMAN, B.S., EVIATAR, J.A., Ophthal. Plast.

Reconstr. Surg., 11, 1995, p. 77-88.

60.DUTTON, J.J ., Ophthalmology, 98, 1991, p. 370-377.

61.HOLMES, R.E., Plast. Reconstr. Surg., 63, 1979, p. 626-633.

62.NUNNERY, W.R., HEINZ, G.W., BONNIN, J.M., MARTIN, R.T., CEPELA, M.A., Ophthal. Plast. Reconstr. Surg., 9, 1993, p. 96-104.

63.BIGHAM, W.J., STANLEY, P., CAHILL, J.M., J R, CURRAN, R.W., PERRY, A.C., Ophthal. Plast. Reconstr. Surg., 15, 1999, p. 317-325.
64.ROSNER, M., EDWARD, D.P., TSO, M.O., Arch. Ophthalmol., 110, 1992, p. 173-174.

65.SIRES, B.S., HOLDS, J B., ARCHER, C.R., KINCAID, M.C., HAGEMAN, G.S., Ophthal. Plast. Reconstr. Surg., 11, 1995, p. 273-277.

66.SAITOH, A., TSUDA, Y., BHUTTO, I.A., KITAOKA, T., AMEMIYA, T., Plast. Reconstr. Surg., 98, 1996, p. 706-710.

67.WIGGS, E.O., BECKER, B.B., Ophthalmic. Surg., 23, 1992, p. 472476.

68.J ORDAN, D.R., KLAPPER, S.R., Ophthalmic. Surg. Lasers, 30, 1999, p. $403-407$.

69.KAO, S.C., CHEN, S., Ophthalmic. Surg. Lasers, 30, 1999, p. 69-71. 70.CHOO, P.H., CARTER, S.R., CRAWFORD, J.B., SEIFF, S.R., Ophthal. Plast. Reconstr. Surg., 15, 1999, p. 77-78.

71.KAO, L.Y., Ophthal. Plast. Reconstr. Surg., 16, 2000, p. 286-288.

72.DEBACKER, C.M., DUTTON, J.J ., PROIA, A.D., HOLCK, D.E., STONE, T., Ophthal. Plast. Reconstr. Surg., 15, 1999, p. 312-316.

73.THAKKER, M.M., FAY, A.M., PIEROTH, L., RUBIN, P.A., Ophthal. Plast. Reconstr. Surg., 20, 2004, p. 368-373.

74.J ORDAN, D.R., ALLEN, L.H., ELLS, A., GILBERG, S., BROW NSTEIN, S., MUNRO, S., GRAHOVAC, S., RAYMOND, F., Ophthal. Plast. Reconstr. Surg., 11, 1995, p. 95-99.

75.SHIELDS, C.L., UYSAL, Y., MARR, B.P., LALLY, S.E., RODRIQUES, E., KHAROD, B., SHIELDS, J .A., Ophthalmology, 114, 2007, p. 367-373.

76.SU, G.W., YEN, M.T., Ophthal. Plast. Reconstr. Surg., 20, 2004, p. 274-280.

77.J ORDAN, D.R., BAWAZEER, A., Ophthal. Plast. Reconstr. Surg., 17, 2001, p. 184-190.

78.MAWN, L.A., JORDAN, D.R., GILBERG, S., Can. J. Ophthalmol., 33, 1998, p. 203-209.

79.J ORDAN, D.R., MUNRO, S.M., BROWNSTEIN, S., GILBERG, S., GRAHOVAC, S., Ophthal. Plast. Reconstr. Surg., 14, 1998, p. 244-249.

80.J ORDAN, D.R., HWANG, I., GILBERG, S., BROWNSTEIN, S., MCEACHREN, T., GRAHOVAC, S., et al., Ophthal. Plast. Reconstr. Surg., 16,2000, p. 363-369.

81.J ORDAN, D.R., CHAN, S., MAWN, L., GILBERG, S., DEAN, T., BROWNSTEIN, S., et al. Ophthalmology, 106, 1999, p. 505-512.

82.J ORDAN, D.R., PELLETIER, C., GILBERG, S.M., BROW NSTEIN, S., GRAHOVAC, S.Z., Ophthal. Plast. Reconstr. Surg., 15, 1999, p. 420-424. 83.REMULLA, H.D., RUBIN, P.A., SHORE, J.W., SUTULA, F.C., TOWNSEND, D.J ., WOOQ, J.J ., et al. Ophthalmology, 102, 1995, p. 586593.

84.J ORDAN, D.R., BROW NSTEIN, S., J OLLY, S.S., Ophthalmology, 103, 1996, p. 1784-1787.

85.OESTREICHER, J.H., LIU, E., BERKOWITZ, M., Ophthalmology, 104, 1997, p. 324-329.

86.J IN, S.M., KIM, J.H., KIM, I.C., J. Korean. Ophthalmol. Soc., 41, 2000, p. 144-156.

87.CHEE, E., KIM, Y.D., WOO, K.I., LEE, J.H., KIM, J.H., SUH, Y.L., Ophthal Plast. Reconstr. Surg., 29, 2013, p. 40-42.

88.JUNG, S.K., CHO, W.K., PAIK, J.S., YANG, S.W., Br. J. Ophthalmol., 96, 2012, p. 494-498.

89.KARESH, J.W., DRESNER, S.C., Ophthalmology, 101, 1994, p. 16881696.

90.BLAYDON, S.M., SHEPLER, T.R., NEUHAUS, R.W., et al. Ophthal. Plast. Reconstr. Surg., 19, 2003, p. 364-371.

91.LEE, S., MARONIAN, N., MOST, S.P., et al. Arch. Otolaryngol. Head. Neck. Surg., 131, 2005, p. 446-450.

92.KLAWITTER, J.J., BAGWELL, J.G., WEINSTEIN, A.M., et al. J. Biomed. Mater. Res., 10, 1976, p. 311-323.

93.SPECTOR, M., FLEMMING, W.R., SAUER, B.W., J. Biomed. Mater. Res., 9, 1975, p. 537-542.

94.KIM, D.H., KOH, Y.M., NA, K.S., J. Korean. Ophthalmol. Soc., 43, 2002, p. 349-356.

95.BAEK, S.H., J. Korean. Ophthalmol. Soc., 41, 2000, p. 1858-1863. 96.BLAYDON, S.M., SHEPLER, T.R., NEUHAUS, R.W., WHITE, W.L., SHORE, J.W., Ophthal. Plast. Reconstr. Surg., 19, 2003, p. 364-371.

97.LEE, C.S., PAIK, H.J ., SONG, M.S., J. Korean. Ophthalmol. Soc., 41, 2000, p. 299-306. 
98.CHOI, A.H., WOOG, J.J., KIM, Y.D., J. Korean. Ophthalmol. Soc., 44, 2003, p. 773-779.

99.GOLDBERG, R.A., DRESNER, S.C., BRASLOW, R.A., KOSSOVSKY, N., LEGMANN, A., Ophthal. Plast. Reconstr. Surg., 10, 1994, p. 104-109. 100.J ORDAN, D.R., BROW NSTEIN, S., DOREY, M., YUEN, V.H., GILBERG, S., Ophthal. Plast. Reconstr. Surg., 20, 2004, p. 136-143.

101.LI, T., SHEN, J., DUFFY, M.T., Ophthal. Plast. Reconstr. Surg., 17, 2001, p. 431-435.

102.KARCIOGLU, Z.A., AL-MESFER, S.A., MULLANEY, P.B., Ophthalmology, 105, 1998, p. 1311-1318.

103.WOOG, J.J ., DRESNER, S.C., LEE, T.S., KIM, Y.D., HARTSTEIN, M.E., SHORE, J.W., et al. Ophthalmic. Surg. Lasers. Imaging., 35, 2004, p. 358-362.

104.RUBIN, P.A., POPHAM, J.K., BILYK, J.R., SHORE, J.W., Ophthal. Plast. Reconstr. Surg., 10, 1994, p. 96-103.

105.NAIK, M.N., MURTHY, R.K., HONAVAR, S.G., Ophthal. Plast. Reconstr. Surg., 23, 2007, p. 463-467.

106.RUBIN, P.A., POPHAM, J., RUMELT, S., REMULLA, H., BILYK, J.R., HOLDS, J., MANNOR, G., MAUS, M., PATRINELY, J.R. ,Ophthalmology, 105, 1998, p. 919-925.

107.ANDERSON, R.L., THIESE, S.M., NERAD, J.A., JORDAN, D.R., TSE, D., ALLEN, L., Ophthalmic Plast. Reconstr. Surg., 8, 1990, p. 88-99. 108.ANDERSON, R.L., YEN, M.T., LUCCI, L.M., CARUSO, R.T., Ophthal. Plast. Reconstr. Surg., 18, 2002, p. 50-55.
109.DEI CAS, R., MAUS, M., BILYK, J., CHANG, W., EAGLE, JR R.C., RUBIN, P., Ophthal. Plast. Reconstr. Surg., 14, 1998, p. 425-431.

110.MORTEMOUSQUE, B., DIEMER, C., LEGER, F., BARACH, D., LEGEAIS, J.M., WILLIAMSON, W., J. Fr. Ophthalmol., 24, 2001, p. 467473.

111.MORTEMOUSQUE, B., LEGER, F., VELOU, S., GRAFFAN, R., COLIN, J., KOROBELNIK, J.F., J. Biomed. Mater. Res., 63, 2002, p. 686-691. 112.MOREL, X., RIAS, A., BRIAT, B., EL AOUNI, A., D'HERMIES, F., ADENIS, J.P., et al. J. Fr. Ophthalmol., 21, 1998, p. 163-169.

113.J ORDAN, D.R., MAWN, L.A., BROW NSTEIN, S., MCEACHREN, T.M., GILBERG, S.M., HILL, V., GRAHOVAC, S.Z., ADENIS, J.P., Ophthal. Plast.Reconstr. Surg., 16, 2000, p. 347-355.

114.CHRISTEL, P. S. 1992", CLIN. ORTHOP. RELAT. RES. 282, 10-18.

115.J ORDAN, D.R., GILBERG, S., MAWN, L.A., Ophthal. Plast. Reconstr. Surg., 19, 2003, p. 128-135.

116.WANG, J.K., LAI, P.C., LIAO, S.L., Am. J. Ophthalmol., 147, 2009, p. 162-170.

117. BEJ AN, C., MATEI, M.N., DOROBAT, C., JUGANARIU, G., DOROBAT, G., CONSTANTINESCU, S., NECHITA, A., EARAR, K. Biochemical Features in Hepato-renal Dysfunctions. REVISTA DE CHIMIE, 66, no.2, 2015, p. 282-284 - 2 citari+4nasa

118. ARBUNE, M., FOTEA, S., NECHITA, A., STEFANESCU, V. Emerging Infection with Elizabethkingia meningoseptica in Neonate. A Case Report. J OURNAL OF CRITICAL CARE MEDICINE, 4, no. 3, 2018, p. 96100.

Manuscris received: 16.07 .2018 